Проаналізовано шляхи розвитку інформаційно-комунікативних технологій у всіх сферах: соціальній, політичній, економічній, культурній, - що зумовлено мережевою логікою розвитку соціальних субеекттів. Проведено аналіз актуальних досліджень, що стосуються проблем формування нової моделі організації соціально-політичного простору, у якому домінують горизонтальні мережеві комунікації та зеявляється безліч різноманітних акторів, котрі беруть участь у перетворенні публічної політики, а також зростають роль і значення мережевих структур, які володіють високим потенціалом самоорганізації й мобілізації. Розглянуто особливості функціонування української політичної системи, що, з одного боку, відображають глобальні тренди формування мережевої публічної політики; з іншого - наявні практики соціальних мереж, не завжди пов язані 3 нарощуванням ресурсів публічності й розвитком демократичних основ політики. Зауважено щодо домінування неформальних політичних комунікаційних практик, імітації публічності, формування кланової політики та патримоніальної політичної системи, що характеризують деструктивний потенціал соціальних мереж. У статті теоретично обгрунтовано концепт «інтернетизація в публічній регіональній політиці», що дає змогу розширити парадигмальне поле політичної науки, а також застосувати мережевий метод до аналізу української публічної політики, що дає можливість не лише пояснити нові соціально-політичні явища, але й визначити нові вектори розвитку сучасної політичної системи України, заснованої на принципах демократичної участі й співпраці держави та громадянського суспільства. Визначено ефекти інтернетизації комунікацій через проникнення мережевого суспільства в публічну політику й дії на неї, що має багатоаспектний характер та проявляються у вигляді змін на різних іiі рівнях, зумовлює появу інноваційних механізмів, котрі відтворюють її новий тип, а саме мережеву публічну політику.

Ключові слова: інформаційні та комунікаційні технології, інтернетизація, соціальне життя, розвиток держави, мережеве суспільство, громадський простір.

Матеріал надійшов до редакції 08.11.2019 р.

УДК 327(510):351.746:007

\title{
Марія Копійка,
}

аспірантка кафедри міжнародних

медіа-комунікацій і комунікативних технологій,

Київський національний університет

імені Тараса Шевченка, Інститут міжнародних відносин,

04119, Україна, м. Київ, вул. Юрія Іллєнка,36/1, к. 262

kopiikams@gmail.com

https://orcid.org/0000-0003-0306-1362

https://doi.org/10.29038/2524-2679-2020-01-68-80

\section{«ГОСТРА СИЛА» В СТРАТЕГІЇ ІНФОРМАЦЙНОЇ БЕЗПЕКИ КИТАЮ}

У статті досліджено конщептуальні й прикладні аспекти «гострої сили» Китаю як нової технології впливу в міжнародній політиці, щзо спрямована на досягнення конкурентних переваг за допомогою інформаційних операцій, кіберзагроз $i$ маніпулювання новинним контентом мас-медіа й сочіальних мереж, проаналізовано

(C) Копійка M., 2020 
зміни в стратегії інформаційної безпеки Китаю з огляду на використання такого інструментарію, як сучасна форма політичної діяльності держави в міжнародних відносинах. Інструментарій «гострої сили» може включати спроби окремих міжнародних акторів управляти інформацією про себе в мас-медіа, освітніх $i$ культурологічних системах іншої країни, аби ввести в оману або розділити громадську думку в обраній країні чи відвернути увагу від негативної інформації про себе. Зокрема, китайські урядові інституиії здійснюють підтримку своєї політики та інформаційної безпеки шляхом нейтралізації критики Китаю за межами країни, намагаються впливати на міжнародну взаємодію через «гостру» дипломатію, яка зумовлюється ідеологією, що підтримує привілеї державної влади над особистою свободою $i \epsilon$ принщипово ворожою для відкритих дискусій та незалежної думки. 3'ясовано, щзо Китай має різні позиції щодо політики «гострої сили» як складової частини інформачійної безпеки на міжнародному й наџіональному рівнях, щуо зумовлюється технологічними інноваціями в телекомунікаціях та сочіальних медіа, які вважаються викликом для глобальної демократії, проведення відповідної правової міжнародної політики та ефективного співробітництва. Уключення контенту «гострої сили» до стратегії інформаційної безпеки Китаю свідчть про спрямоване позиціонування політики країни у світі, оперативне реагування щуодо забезпечення національних інтересів і формування прийнятної для Китаю громадської думки щуодо ролі держави в прочесах глобального управління.

Ключові слова: міжнародні відносини, «гостра сила», інформаційна безпека, кібербезпека, сочіальні мережі, інститут Конфуція, Китай.

\section{1. ВСТУП}

Постановка проблеми. Сучасний розвиток міжнародної системи викликав якісні зміни принципів міждержавних відносин і практичних механізмів та технологій реалізації стратегій інформаційної безпеки, зважаючи на те, що потенціал таких впливів передбачає відповідні ресурси, котрі визначають переваги держав на світовій арені. Використання високих технологій як інструментарію політичного тиску для забезпечення національних інтересів у міжнародній взаємодії, розробка й упровадження інноваційних стратегій національної безпеки вплинули на класичне розуміння «балансу сил», зумовили еволюцію концепту сили від «жорсткої», а згодом «меякої/розумної» до «гострої», яка наразі впливає на глобальне інформаційне протиборство. Як зазначає Дж. Най-молодший, «гостра сила» передбачає «спроби однієї країни маніпулювати та управляти інформацією у мас-медіа й освітній сфері іншої держави, щоб увести в оману, розділити/збурити громадську думку в обраній країні або відвернути увагу політикуму та суспільства від негативної інформації про себе» [1]. Поширення стратегії «гострої сили» в зовнішній i безпековій політиці держав, на думку експертів, полягає в тому, що певні «авторитарні держави намагаються впливати через політику «гострої сили» на ідеологію державної влади й масову свідомість спільноти інших міжнародних акторів для забезпечення власних геополітичних переваг у глобальній конкуренції. Потрібно зазначити, що практика «гострої сили» відрізняється від одного політичного режиму до іншого, але, зазвичай, передбачає цензуру та поширення спрямованої інформації, призначених не для репутаційного 
завоювання громадськості, а для руйнування цілісності незалежних інституцій». Тобто в експертному середовищі вважається, що дослідження щодо стратегій і практики «гострої сили» в міжнародних відносинах стають усе більш важливими, оскільки «певні авторитарні країни намагаються розширити свій вплив по всьому світу, використовуючи непрозорі та сумнівні засоби для обговорення «чутливих і вразливих» питань у глобальному масштабі» [2].

Аналіз останніх досліджень і публікацій. У сучасному політичному дискурсі щодо еволюції концепцій сили в міжнародних відносинах i використання «гострої сили» в стратегіях інформаційної безпеки представлені як дослідження загального характеру, зокрема праці відомих фахівців із теорії сили в міжнародних відносинах Р. Армітіджа, 3. Бжезинського, Р. Кеохейна, Г. Кіссинджера, Г. Лассвелла, Р. Литтла, Г. Моргентау, Дж. Ная-мол., Дж. Розенау, К. Уолца, М. Шихана та ін., так і наукові праці Т. Беннера, К. Волкера, К. Ші-Купфер, С. Лю, М. Сімона, К. Техвана, А. Фульди, М. Шнайдера щодо стратегії «гострої сили» Китаю, у яких стверджується, що «посилення авторитаризму як домінуючої політичної форми в усьому світі зумовило суттєве використання «гострої сили» як стратегічної зброї, що порушує норми внутрішньої поведінки демократичних держав за допомогою способу, котрий є сприятливим для авторитарних режимів». Зокрема, еволюція концепцій сили, за Р. Армітіджем, Т. Беннером, П. Беєюкененом, Ш. Калатхил,

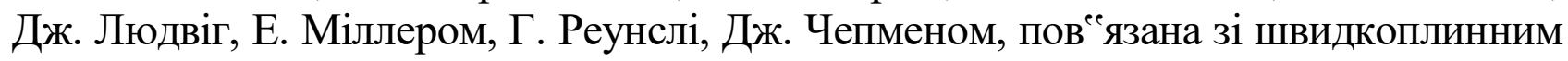
постіндустріальним розвитком, формуванням нової архітектури світового порядку, розробкою нових правил міжнародної взаємодії з урахуванням реалій цифрової революції, домінуванням інтелектуальних ресурсів у міжнародних відносинах та модернізацією технологій у безпековій сфері [3-9].

У вітчизняній політології наукові дослідження В. Бебика, Д. Дубова, О. Кучмій, Є. Макаренко, М. Ожевана, Н. Піпченко, Г. Почепцова, М. Рижкова, О. Фролової та ін. із проблематики міжнародної інформаційної безпеки й інформаційної безпеки Китаю, зокрема, стосуються визначення природи та сутності «сили» в зовнішній політиці держав, подолання конфліктності стратегій міжнародної інформаційної безпеки, з ясування практики інформаційних та гібридних війн, технологій i методів протидії ворожій інформаційній агресії й нейтралізації деструктивних інформаційних впливів. Фахівці вважають, що стратегії інформаційної безпеки мають грунтуватися на врахуванні динамічних змін сучасної політичної реальності, проведенні прикладних досліджень щодо еволюції сили в міжнародних відносинах i впровадженні ефективних механізмів забезпечення інформаційної безпеки [1016]. Дослідження наукової проблеми використання «гострої сили» у сфері інформаційної безпеки зумовлює необхідність цілісного аналізу сучасного інструментарію інформаційного протиборства, зеясування наслідків впливу політики «гострої сили» на міжнародну взаємодію, а також на формування механізмів протидії деструктивним впливам в умовах гібридних конфліктів.

Формулювання цілей статті. Мета роботи - з ясування концепту «гострої сили» в стратегії та практиці інформаційної безпеки Китаю. 


\section{2. РЕЗУЛЬТАТИ ДОСЛІДЖЕННЯ}

Виклад основного матеріалу й обгрунтування результатів дослідження. Значний внесок у тлумачення поняття «сила» зробили відомі дослідники P. Кеохейн та Дж. Най, які в праці «Power and Interdependence: World Politics in Transition» (1977 р.) сформулювали теорію «комплексної взаємозалежності», надавши поняттю «сила» нового значення. Теорія спростовує твердження про визначальну роль військової потужності держави в здійсненні зовнішньої політики та наголошує на необхідності модернізації сили згідно зі становленням нових форм міжнародних відносин. Р. Кеохейн i Дж. Най визначили «силу» як «здатність субесккта змусити інших зробити щось, чого вони раніше не робили, й при цьому - за прийнятною «ціною». Для кращого розуміння цієї здатності за взаємозалежності держав уведено два додаткові поняття «чутливість» i «вразливість», якими дослідники визначили неолібералістичне розуміння поняття «сила». Під «чутливістю» фахівці розуміли те, як швидко зміни в одній державі призводять до відчутних змін в іншій і наскільки значними є ці наслідки». Що ж стосується «вразливості», то вона, на думку науковців, залежить від відносної доступності та ціни альтернатив, перед якими постають різні актори» [17].

У вітчизняних дослідженнях значущість політики сили Китаю пов язується зі стрімким економічним, технологічним і військовим розвитком держави, що сприяло відновленню іiі регіонального лідерства й конкуренції в глобальному управлінні. Такий прогрес і видимі перспективи, як зазначають фахівці, можуть мати небезпечні наслідки для всієї міжнародної системи, оскільки свідчать про подальше домінування Китаю в регіоні, а також про зміцнення військової присутності держави щодо стримування геостратегічних інтересів інших країн, передусім США, у сфері безпеки й міжнародної торгівлі, що створюють цілісний комплекс можливостей для просування китайської політики лідерства» $[12 ; 13]$.

Водночас Дж. Най-мол. у статті «How Sharp Power Threatens Soft Power» (2018 р.) зазначав, що стратегія «гострої сили» за своїм концептом значно відрізняється від стратегії «меякої/розумної сили», яка означає здатність ефективно обее єднувати «жорстку» та «меяку» силу, щоб створити позитивне враження про зовнішньополітичну діяльність і впливати на позицію іншої країни через переконання політикуму й спільноти в правильності урядових керівних рішень. Стратегія «гострої сили» також відрізняється від «жорсткої сили», яка визначається як примушення через військову, економічну та фінансову силу змінити політику іншої країни у своїх інтересах [18].

Американські дослідники К. Волкер, Д. Людвіг і Ш. Калатхіл використали нове поняття «гостра сила» для розеяяснення сучасної політики Китаю як типового прикладу «авторитарної меякої сили», яка «проникає або пронизує політичне та інформаційне середовище в цільових країнах» через використання «зовнішньої цензури, маніпулювання й відволікання уваги від гострих проблем міжнародної взаємодії». Фахівці наголошували, що авторитарні держави 
намагаються впливати через «гостру силу» для нейтралізації критики за кордоном і водночас представити демократію менш привабливою ідеологією шляхом інформаційних атак на цілісність демократій та ідеї, що покладені в основу демократичних систем. У коментарях експертів чітко простежуємо думку, що Китай та інші авторитарні режими через використання «гострої сили» проектують збільшення політичного впливу у своїх регіонах і у світі загалом, а посилення «гострої сили» за останні десятиліття, зумовленої інноваційними телекомунікаціями, пояснюється певною кризою глобальної демократії, а також є викликом для неї [5; 6].

У цьому ж контексті китайські вчені наголошують, що авторитарні держави декларують ідеї та цінності, які конструюються як дискурси й «стратегічні наративи» для формування спільного контенту минулого, сьогодення та майбутнього міжнародних відносин і для відповідної поведінки політичних акторів. Так, у праці С. Лю «What Sharp Power? It"s Nothing But «Unsmart» Power» зазначено, що наразі стратегічні наративи Китаю мають дві складові частини: бачення китайської перспективи й підтримка традиційних китайських цінностей, орієнтованих на конфуціанство задля забезпечення конкурентного світового лідерства держави. У наративі пропагується ідея, що до 2050 р. відбудеться становлення «помірковано процвітаючого суспільства» (2021 р.); відзначення століття Комуністичної партії Китаю й набуття державою статусу світового лідера під гаслом «великого омолодження китайської нації»; формування «цілком розвиненої держави» (2049 р.). Водночас залучення до наративу цінностей конфуціанства, як стверджується в політичних заявах лідерів Китаю, убезпечить китайську націю «від зараження корумпованою західною ліберальною ідеологією». Отже, Китай сподівається поширювати свої дискурсивні стратегічні наративи, які містять елементи неліберальних цінностей і світогляду, у різних сферах міжнародних відносин за допомогою ресурсу «гострої сили», що охоплює дипломатію, безпеку, освітню й культурну діяльність, а також сучасні медійні та інтернет-комунікації [8; 10].

Політика «гострої сили» у сфері дипломатії й інформаційної безпеки, як наголошується в розвідках міжнародних аналітиків, свідчить про геополітичні амбіції та прагнення Китаю й характеризується як «операції зовнішнього

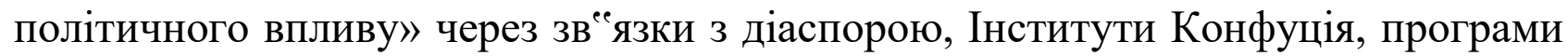
освітніх обмінів і наукових досліджень. Останнім часом спостерігаємо активні ініціативи урядових інститутів Китаю щодо залучення зарубіжної діаспори чисельністю понад шістдесят мільйонів громадян китайського походження до поширення наративів «гострої влади» в країнах перебування. При цьому зарубіжні китайці розглядаються не лише як провідники пропаганди й реалізації політики КНР, але і як активісти з протидії антикитайській діяльності політичних захисників прав людини й демократії в Китаї, тибетських «сепаратистів» та прихильників незалежності Тайваню. Ідеться про організацію Асоціацією китайської діаспори контрдемонстрацій проти антикитайських мітингів Фалуньгун і протибетських груп. До таких демонстрацій під гаслом «патріотичного виховання» й формування багатовимірних мереж між 
материковим Китаєм, китайськими іноземними студентами та зарубіжними місіями, зокрема в США, уключають «близько 150 китайських студентських i наукових асоціацій», які виступають проти лекцій, форумів та інших заходів, що $є$ критичними для Китаю, на території й поза межами освітніх закладів [19].

Чинником «гострої сили» інформаційної безпеки Китаю наразі вважається також діяльність Інститутів Конфуція, які відносять до компетенції Міжнародного бюро Ради Китаю 3 поширення культури, мови та наукових й освітніх грантів у зарубіжжі, чисельність котрих поза материковим Китаєм у 2019 р. досягла 530 відділень і понад 1000 класів, які не лише представляють «офіційну версію Китаю», як це передбачено урядовими освітніми й культурними інститутами, а й навчальними програмами, що містять проблематику таких «чутливих» тем, як політика щодо Тибету, Сіньцзяню, Тайваню, Далай-лами, Тяньаньменю, Фалуньгуню і прав людини в Китаї. Через повноваження Міністерства освіти щодо затвердження щорічних бюджетних проектів для інститутів Конфуція партнерські установи та експерти, з огляду на можливість припинення фінансових потоків із Пекіна й можливих негативних впливів на особисту професійну кар єру, перебувають під наявним примусом самоцензури. Практично таким чином Пекін здійснює прямий i непрямий політичний тиск на роботу організацій та освітніх закладів, які $є$ кризисно важливими для Китаю і які можуть сприяти перспективній підтримці позицій держави щодо критичних політичних питань. Крім того, задля співпраці 3 лідерами думок й академічними установами через політичні та фінансові інвестиції благодійного характеру використовуються можливості китайських підприємців із неявними та явними звеяззками з державними органами КНР. Ураховуючи, що численні Інститути Конфуція діють безпосередньо в університетських містечках зарубіжних країн, виникають певні проблеми, повеязані з академічною свободою, програмами академічних обмінів, грантами й стипендіями для іноземних науковців і китайських студентів. Так, політику «гострої сили» застосовано для тиску на університети в країнах усталеної демократії, коли Китайська рада стипендій як філіал міністерства освіти Китаю (2017 р.) перестала приймати заявки на отримання стипендій від китайських аспірантів і науковців, котрі бажали навчатися в Каліфорнійському університеті в Сан-Дієго після того, як Далай-лама під час візиту до США повідомив адресу коледжу для тибетських й іноземних студентів у тантричному монастирі Г’юдмед. Крім того, Інститути Конфуція розглядаються Пекіном як структури потужного інформаційного впливу на освітні заклади, у котрих відсутні ресурси для запровадження власних спеціальностей із китайської мови та забезпечення їх відповідними навчальними програмами. Водночас китайська влада заперечує порушення академічної свободи в межах діяльності інститутів Конфуція, оскільки, на думку Ван Гоцина, представника Китайської народної політичної консультативної конференції, підтримка уряду не означає, що установи, безперечно, є провідниками політики «гострої сили» Китаю, крім окремих випадків, що призвели до розформування деяких інститутів Конфуція у впливових країнах світу. А звинувачення політиків у тому, що Китай 
просуває свою ідеологію й цінності в політичному та інформаційному середовищі інших країн, за Ван Гоцином, свідчить про упереджене ставлення, дискримінацію та вороже сприйняття позиції держави в міжнародних відносинах $[20 ; 21 ; 22]$.

Науковці, аналізуючи Стратегію національної безпеки Китаю попередніх років, звертають увагу на тезу про «непередбачувані» та «безпрецедентні» загрози, із якими стикається держава на національному й міжнародному рівнях діяльності. Загальний контент проблем, які вважалися важливими для Пекіна, стосувалися змін міжнародного середовища; глибоких економічних i соціальних трансформацій на національному рівні; критичності періоду для здійснення реформ; наявності численних «соціальних суперечностей». При цьому ключовою частиною стратегії національної безпеки Китаю визнавалися інформаційні загрози - від кібератак до тероризму. Відповідно, стратегія інформаційної безпеки передбачала формування ефективного механізму оборонної стратегії щодо протидії інформаційним загрозам як для внутрішньополітичної стабільності китайського суспільства й функціонування національної інформаційної інфраструктури, так і для розробки наступальної стратегії щодо потенційних супротивників i нейтралізації можливої інформаційної інтервенції ззовні. Внутрішньополітична ситуація в Китаї розглядалася як чинник стратегічного значення, оскільки їі нестабільність могла стати спонукальним мотивом втручання у внутрішні справи держави й навіть гібридної агресії, викликом для національної єдності країни [14; 23$]$.

Особливості реалізації китайської політики інформаційної безпеки того часу неоднаково оцінювались експертами. Зокрема, представники західних кіл характеризували систему жорсткого контролю за інформацією й інформаційною діяльністю китайських громадян як тотальну, що стримує демократизацію країни та формування відкритого інформаційного суспільства. Натомість уряд Китаю вважав, що подібний контроль є необхідною умовою формування національного інформаційного простору й гарантією безпеки політичної, економічної та професійної діяльності. Відтак за «Правилами регулювання, що забезпечують безпеку комп ютерних та інформаційних систем» (1994р.), «заборонялося розміщення в мережі Інтернет-закликів до невиконання або ж порушення державних законів, нормативних актів чи ж Конституції; закликів до зміни комуністичної ідеології або державної системи; закликів до порушення цілісності країни; інформації націоналістичного характеру; поширення неправдивої інформації, чуток; пропаганди феодального ладу; поширення матеріалів порнографічного характеру; пропаганди азартних ігор; пропаганди насильства; закликів до терористичної діяльності; дискредитації державних органів» [14; 23]. Наразі в Китаї, - підкреслюється в експертній аналітиці, - «функціонує складна система файрволлів, яка обмежує доступ до проблемних зовнішніх ресурсів і застосовується провайдерами не лише для захисту від вірусів і хакерів, але й для блокування доступу до певних сайтів, що містять небажану для політичного режиму інформацію». Фільтрації, піддаються ресурси західних мас-медіа, такі як сайти ВBC, CNN, ABC i CBS 
News, журнал «Тіme», сайти більшості американських університетів, пошукова система Alta Vista. Також у китайському Інтернеті обмежені можливості розміщення новин, крім повідомлень, які вже опубліковані на офіційних сайтах, або передруковані 3 офіційних друкованих медіа. Фактично йдеться про інформаційне залякування політичної опозиції, конкуренцію інформаційних потенціалів та інформаційних стратегій, використання інформаційних озброєнь, інформаційну агресію економічного і культурного змісту, інформаційні війни в контексті «гострої сили» [14; 23].

Безпекового аспекту «гострої сили» Китаю стосується аналітичне дослідження представника Інституту Гувера з питань війни, революції та миру К. Паркера «China Exerting „Sharp Power" Influence On American Institutions», y якому стверджується, що «прагнення до глобальної гегемонії й маніпулювання політичними опонентами $\epsilon$ рушійною силою Китаю». Підставою для такого висновку фахівець уважає, що Китай наразі $є$ «справжньою супердержавою із погляду глобального охоплення, впливу й амбіцій», випереджаючи багато в чому інших міжнародних акторів; Китай стрімко набуває переваг у передових галузях технологічного, економічного та потенційно військового характеру, зокрема через привласнення західної (особливо американської) інтелектуальної власності; Китай для досягнення своїх глобальних амбіцій використовує нову форму влади - «гостру силу», яка «прагне проникнути до інститутів демократії, щоб зруйнувати ліберальний міжнародний порядок і трансформувати його у власний авторитарний i глибоко корумпований режим»; Китай шукає домінування, він діє на світовій арені за своїми правилами». У дослідженні наголошено, що до таких висновків науковця спонукали висловлювання китайських студентів, котрі позитивно сприйняли атмосферу інтелектуальної свободи в США, китайських підприємців, які емігрували до США через відсутність безпеки для своїх прав власності й поширеного рівня корупції в країні, а також китайські американці, які занепокоєні негативним китайським впливом на основні права й свободи людини [24]. Ці аргументи підтримує й американський політик й публіцист П. Б“еюкенен, який характеризує політику «гострої сили» як спецоперації за участю хакерів та кампанії з дезінформації в соціальних мережах, якими підривається довіра до державних інституцій та управлінських рішень. До них він відносить розміщення так званих «підроблених новин» у відомих соціальних мережах, зловмисне руйнування банківських систем і державних урядових структур, відповідальних за базове забезпечення громадської життєдіяльності, автоматичні порушення інфраструктури й прихований контроль над цільовими мас-медіа. Використання методів «гострої сили», - стверджує П. Беєюкенен, - уможливлює приховування місць походження кібератак чи фейків, оскільки вони поширюються через системи третіх сторін або розміщуються на відкритих платформах партій, що вдаються до маскування таких інтервенцій. Крім того, зазначені зловмисні заходи здійснюються спільно з традиційним шпигунством та операціями впливу в багатогранній стратегії, спрямованій на підрив ідеологічних й інституційних основ демократичних суспільств. Практично 
«втрата віри і довіри до ліберальної демократії» розглядається дослідником як перемога «гострих владних сил» $[4 ; 25 ; 26]$.

На сучасному етапі стратегія інформаційної безпеки Китаю охоплює експортування політичних цінностей, норм і моделі управління державою як складової частини зовнішньої політики й міжнародної взаємодії, щоб протидіяти будь-яким сценаріям лібералізації політичної влади в країні. Водночас використання непрозорих інструментів «гострої сили» для забезпечення геополітичних прагнень, зокрема маніпулювання, дезінформації та інформаційної інтервенції, негативно впливає на ставлення політикуму й спільноти зарубіжних країн до дій Китаю як у регіональному, так i в глобальному форматі відносин. Водночас експерти в зарубіжних країнах розходяться в оцінках ризиків інтеграції Китаю в економічне, політичне та культурне життя західних країн, вразливих до тиску «гострої сили», оскільки влада Китаю намагається протистояти демократизації країни за західною моделлю й заборонити вільний доступ до інформаційних ресурсів для всього китайського суспільства. Крім того, практика вкладання китайських інвестицій у багаті країни, уключаючи ресурси, стратегічну інфраструктуру, інноваційні технології та сільськогосподарський сектор, свідчить про використання Китаєм різних складових частин «гострої сили» щодо формування порядку глобального управління, створеного переважно Америкою й Західною Свропою. Водночас експерти підкреслюють, що, незважаючи на значні зусилля, авторитарні режими відчувають гострий дефіцит самоствердження, про що свідчать від ємні показники в глобальних опитуваннях громадської думки, а також у рейтингах «меякої сили», що підтверджує ідею про несумісність авторитаризму 3 привабливістю та силою переконання. Але, незважаючи на такі результати, ступінь міжнародного впливу Китаю й інших амбітних режимів, забезпечених ресурсами, наразі вищий, ніж в інші періоди новітньої історії, і цей вплив виявляється саме за допомогою «гострої сили» [27; 28].

\section{3. ВИСНОВКИ ТА ПЕРСПЕКТИВИ ПОДАЛЬШИХ ДОСЛІДЖЕНЬ}

Отже, трансформація концепцій сили в міжнародних відносинах зумовлюється турбулентними процесами конкурування за світове лідерство між провідними міжнародними акторами, викликає загострення міжурядових контактів і використання відповідних технологій впливу на політичні еліти та громадську думку, зокрема у сфері інформаційної безпеки. «Гостра сила» як чинник стратегії інформаційної безпеки Китаю реалізується через механізми дипломатичного, культурного та освітнього характеру, а також через мас-медіа й соціальні мережі, що надає можливість урядовим структурам китайської держави правомірно чи неправомірно протидіяти викликам для національних інтересів Китаю в сучасному світі.

\section{СПИСОК ВИКОРИСТАНИХ ДЖЕРЕЛ}

1. Nye, J. S., Jr. (2018, January 24). How Sharp Power Threatens Soft Power. Retrieved from. URL: https:// www.f oreignaffairs. com/ articles/ china/2018-01-24/how-sharp-powerthreatens-soft-power 
2. Walker, Ch. (2018). The point of sharp power. URL: https:// www. japantimes. co.jp/opinion/2018/02/12/commentary/world-commentary/point-sharp-power/\#.XFAUkixS_cs

3. Nye, J. S. A smarter, more secure America. Report of the CSIS Commission on Smart Power/Craig Cohen, Joseph S. Nye, Richard Armitage: URL: http://csis.org/publication/smartermore-secure-america

4. Buchanan, P. (2018). Confronting Sharp Power. URL: https://36th-parallel. com/ 2018/ 10/ 24/confronting-sharp-power/magical-weapons

5. Walker, Ch., Kalathil, Sh., Ludwig, J. (2018). Soft power is out; sharp power is in. Here's how to win the new influence wars. URL: https:// foreignpolicy. com/ 2018/09/14/forget-hearts-andminds-sharp-power/

6. Chapman, J. Democracies Should Fight Sharp Power with Soft Power. URL: https://www.pacificcouncil.org/newsroom/democracies-should-fight-sharp-power-soft-power

7. Rawnsley, G. (2017). On so-called «Sharp Power». URL: http:// wwwpdic .blogspot. com/ 2017/12/on-so-called-smart-power.html

8. Xin, Liu. What Sharp Power? It's Nothing But «Unsmart» Power. URL: https://www.uscpublicdiplomacy.org/blog/what-sharp-power-it\%E2\%80\%99s-nothing\%E2\%80\%9Cunsmart\% E2\%80\%9D-power

9. Miller, A. (2017). Can Soft Power Work in a Sharp Power World? URL: https:// www.usip.org/publications/2018/11/can-soft-power-work-sharp-power-world

10. Бебик, В. М. (2017). Інформаційне суспільство Китаю: мас-медіа, мережі, безпека. Міжнародні відносини. Політичні науки, № 17. URL: http://journals.iir.kiev.ua/index.php/ pol_n/article/view/3317

11. Дубов, Д. В. (2014). Кіберпростір як новий вимір геополітичного супернищтва: монографія. Київ: НІСД, 328 с.

12. Кучмій, О. П. Стратегія інформаційної безпеки в структурі внутрішньої й зовнішньої політики КНP. URL: http://journals. iir.kiev.ua /index.php/ apmv/ article/view/2138

13. Хуан, Цинь (2007). Информационная политика Китая в современных международных отношениях (Дис. ... канд. полит. наук: 23.00.03)/Киевский национальный ун-т им. Тараса Шевченко. Киев, 236 с.

14. Міжнародна інформачійна безпека: теорія і практика: підручник/Макаренко С. А, Рижков М. М., Ожеван М. М., Кучмій О. П., Фролова О. М. Київ: «Центр вільної преси», 2016. $418 \mathrm{c}$.

15. Піпченко, Н. О. (2014). Інтернет-технології у структурі зовнішньої політики Китаю. Соціальні медіа у структурі зовнішньої політики провідних міжнародних акторів: монографія. Київ: Центр вільної преси, С.195-210.

16. Почепцов, Г. Г. (2019). Фейк: технологія спотворення реальності. Київ: Вид. дім KMA, $175 \mathrm{c}$.

17. Keohane, R., Nye, J. (1977). Power and Interdependence World Politics in Transition. Publisher: Little, Brown and Company; Underlining edition. 287 p.

18. Nye, J. (2018). How Sharp Power Threatens Soft Power. URL: https://www.foreignaffairs.com/articles/china/2018-01-24/how-sharp-power-threatens-soft-power

19. Taehwan, Kim (2018). Authoritarian Sharp Power: Comparing China and Russia. URL: http://www.theasanforum.org/authoritarian-sharp-power-comparing-china-and-russia/

20. Isackson, P. The Role of Sharp Power in Diplomacy. URL: https://www.fairobserver.com/region/north_america/soft-power-hard-power-joseph-nye-diplomacy-world-politicsnews-today-56123/

21. The sharp power of development diplomacy and China's edge. URL: https://www.orfonline.org/expert-speak/sharp-power-development-diplomacy-china-edge

22. Nye, J. S. China's soft and sharp power. URL: https://www.aspistrategist.org.au/chinassoft-sharp-power/

23. Tiezzi, Sh. China's National Security Strategy. URL: https://thediplomat.com/ 2015/01/chinas-national-security-strategy 
24. Parker Clifton, B. China Exerting 'Sharp Power' Influence On American Institutions. URL: https://www.hoover.org/news/china-exerting-sharp-power-influence-american-institutions

25. Benner, T. Ewert, I., Shi-Kupfer, K., Siemons, M., Fulda, A. How To Fight China's Sharp Power. URL: http://www.chinafile.com/conversation/how-fight-chinas-sharp-power

26. China now using 'sharp power' to defend its interests: US think-tank. URL: https://www.straitstimes.com/world/united-states/china-now-using-sharp-power-to-defend-itsinterests-us-think-tank

27. Diamond, L., Carson, B. (2019). Jaw-Jaw: How Chinese Sharp Power Takes Aim at American Democracy. URL: https://warontherocks.com/2019/02/jaw-jaw-how-chinese-sharppower-takes-aim-at-american-democracy

28. Custer, S., Russell, B., DiLorenzo, M., Cheng, M., Ghose, S., Desai, H., Sims, J., Turner, J. (2019). Ties That Bind: Quantifying China's public diplomacy and its "good neighbor» effect. URL: http://docs.aiddata.org/ad4/pdfs/Ties_That_Bind--Full_Report.pdf

\section{«SHARP POWER» IN THE INFORMATION SECURITY STRATEGY OF CHINA}

The article explores the conceptual and applied aspects of China's "sharp power" as a new technology of influence on international policy aimed at achieving competitive advantages through information operations, cyber threats and manipulation of news content in media and social networks. Also, the changes in China's information security strategy have been analyzed considering the use of such tools as a modern form of political activity in international relations. The "sharp power" tools may include attempts by some international actors to manage information on themselves in another country's media, education and cultural systems for misleading or dividing public opinion in the chosen country or for distracting from negative information on themselves. In particular, Chinese government institutions support the policy and information security for counteracting China's criticism outside and impacting on international interactions through "sharp" diplomacy. "Sharp" diplomacy is an ideology that supports the privilege of state power above personal freedom and is fundamentally hostile for open discussions and independent thought. It is found that China has different positions on "sharp power" policy as a component of information security at the international and national levels that depends on technological innovations in telecommunications and social media which are a challenge for global democracy, legal international policy and effective cooperation. Incorporating "sharp power"e into China's information security strategy enables more active promotion of the country's policy abroad, respond promptly to national interests and understand public opinion on China's role in global governance.

Key words: international relations; "sharp power"; information security, cybersecurity, social networks, the Confucius Institute; China.

\section{REFERENCES}

1. Nye, J. S., Jr. (2018, January 24). How Sharp Power Threatens Soft Power. Retrieved from. URL: https:// www.f oreignaffairs. com/ articles/ china/2018-01-24/how-sharp-powerthreatens-soft-power

2. Walker, Ch. (2018). The point of sharp power. URL: https://www.japantimes.co.jp/opinion/ 2018/02/12/commentary/world-commentary/point-sharp-power/\#.XFAUkixS_cs

3. Nye, J. S. A smarter, more secure America. Report of the CSIS Commission on Smart Power / Craig Cohen, Joseph S. Nye, Richard Armitage: URL: http://csis.org/publication/smartermore-secure-america

4. Buchanan, P. (2018). Confronting Sharp Power. URL: https://36th-parallel.com/2018/10/24/ confronting-sharp-power/magical-weapons 
5. Walker, Ch., Kalathil, Sh., Ludwig, J. (2018). Soft power is out; sharp power is in. Here's how to win the new influence wars. URL: https:// foreignpolicy. com/2018/09/14/forget-hearts-andminds-sharp-power/

6. Chapman, J. Democracies Should Fight Sharp Power with Soft Power. URL: https://www.pacificcouncil.org/newsroom/democracies-should-fight-sharp-power-soft-power

7. Rawnsley, G. (2017). On so-called «Sharp Power». URL: http://wwwpdic.blogspot.com/ 2017/12/on-so-called-smart-power.html

8. Xin, Liu. What Sharp Power? It's Nothing But «Unsmart» Power. URL: https://www.uscpublicdiplomacy.org/blog/what-sharp-power-it\%E2\%80\%99s-nothing-\%E2\%80\%9Cunsmart\% E2\%80\%9D-power

9. Miller, A. (2018). Can Soft Power Work in a Sharp Power World? URL: https://www.usip.org/publications/2018/11/can-soft-power-work-sharp-power-world

10. Bebyk, V. M. (2017). Informatsiyne suspil'stvo Kytayu: mas-media, merezhi, bezpeka. Mizhnarodni vidnosyny. Politychni nauky, № 17. URL: http://journals.iir.kiev.ua/index.php/ pol_n/article/view/3317

11. Dubov, D. V. (2014). Kiberprostir yak novyy vymir heopolitychnoho supernytstva: monohrafiya. Kyiv: NISD, 2014. 328 p.

12. Kuchmiy, O. P. Stratehiya informatsiynoyi bezpeky $v$ strukturi vnutrishn'oyi $y$ zovnishn'oyi polityky KNR. URL: http:// journals. iir.kiev. ua/index. php/ apmv/ article/view/2138

13. Khuan, Tsin'. (2007). Informatsionnaya politika Kitaya $v$ sovremennykh mezhdunarodnykh otnosheniyakh: dis. ... kand. polit. nauk: 23.00.03 / Kiyevskiy natsional'nyy un-t im. Tarasa Shevchenko. Kyiv, 236 p.

14. Mizhnarodna informatsiyna bezpeka: teoriya i praktyka. Pidruchnyk/Makarenko YE. A, Ryzhkov M. M., Ozhevan M. M., Kuchmiy O. P., Frolova O. M. Kyiv: «Tsentr vil'noyi presy», 2016. 418 p.

15. Pipchenko, N. O. (2014). Internet-tekhnolohiyi u strukturi zovnishn'oyi polityky Kytayu. Sotsial'ni media u strukturi zovnishn'oyi polityky providnykh mizhnarodnykh aktoriv: monohrafiya. Kyiv: Tsentr vil'noyi presy, P. 195-210.

16. Pocheptsov, H. H. (2019). Feyk: tekhnolohiya spotvorennya real'nosti. Kyiv: Vyd. dim KMA, 175 p.

17. Keohane, R., Nye, J. (1977). Power and Interdependence World Politics in Transition. Publisher: Little, Brown and Company; Underlining edition, $287 \mathrm{p}$.

18. Nye, J. (2018). How Sharp Power Threatens Soft Power. URL: https://www.foreignaffairs.com/articles/china/2018-01-24/how-sharp-power-threatens-soft-power

19. Taehwan, Kim. Authoritarian Sharp Power: Comparing China and Russia. URL:

http://www.theasanforum.org/authoritarian-sharp-power-comparing-china-and-russia/

20. Isackson, P. The Role of Sharp Power in Diplomacy. URL: https://www.fairo-

bserver.com/region/north_america/soft-power-hard-power-joseph-nye-diplomacy-world-politicsnews-today-56123/

21. The sharp power of development diplomacy and China's edge. URL: https://www.orfonline.org/expert-speak/sharp-power-development-diplomacy-china-edge

22. Nye, J. S. China's soft and sharp power. URL: https://www.aspistrategist.org.au/chinassoft-sharp-power/

23. Tiezzi, Sh. China's National Security Strategy. URL: https://thediplomat.com/ 2015/01/chinas-national-security-strategy

24. Parker Clifton, B. China Exerting 'Sharp Power' Influence On American Institutions. URL: https://www.hoover.org/news/china-exerting-sharp-power-influence-american-institutions

25. Benner, T. Ewert, I., Shi-Kupfer, K., Siemons, M., Fulda, A. How To Fight China's Sharp Power. URL: http://www.chinafile.com/conversation/how-fight-chinas-sharp-power

26. China now using 'sharp power' to defend its interests: US think-tank. URL: https://www.straitstimes.com/world/united-states/china-now-using-sharp-power-to-defend-itsinterests-us-think-tank 
27. Diamond, L., Carson, B. Jaw-Jaw: How Chinese Sharp Power Takes Aim at American Democracy. URL: https://warontherocks.com/2019/02/jaw-jaw-how-chinese-sharp-power-takesaim-at-american-democracy

28. Custer, S., Russell, B., DiLorenzo, M., Cheng, M., Ghose, S., Desai, H., Sims, J., Turner, J. Ties That Bind: Quantifying China's public diplomacy and its "good neighbor» effect. URL: http://docs.aiddata.org/ad4/pdfs/Ties_That_Bind--Full_Report.pdf

Матеріал надійшов до редакції 10.12.2019 р.

УДК 327.5:004]:28+316.485.26:316.776.23

Пшемислав Мазур,

доктор політологічних наук,

доцент, Інститут наук про безпеку Педагогічного університету

імені Комісії народної освіти в Кракові (Польща)

https://orcid.org/0000-0003-0025-9410

Анна Нетреба,

випускниця спеціальності «Національна безпека»,

студентка 1 курсу магістратури спеціальності «Державна безпека»,

Інститут наук про безпеку Педагогічного університету

імені Комісії народної освіти в Кракові (Польща)

https://doi.org/10.29038/2524-2679-2020-01-80-93

\section{Е-ДЖИХАД. ІНФОРМАЦІЙНА БОРОТЬБА АЛЬ-КАЇДИ Й ІСЛАМСЬКОЇ ДЕРЖАВИ НА «СТЕЖЦІ БОГА»: ВИБРАНІ ПРИКЛАДИ}

У статті розглянуто питання е-джихад (кіберджихад) як ведення джихаду 3 використанням інформаційних засобів. Зазначено, щзо мовна обсерваторія Варшавського університету зареєструвала слово «кіберджсихад» у 2016 р. У «Словнику польської мови» зазначено, щэо ие «дії проти невіруючих і послідовників інших релігій, котрі проводяться ісламськими фундаменталістами в Інтернеті». Однак таке визначення дуже неточне й навіть частково хибне. Джихад $є$ поняттям дуже розмитим і складним. Історію використання джихадистами Інтернету розділено на три основні періоди. Перший спостерігали до атаки на World Trade Center (11 вересня 2001 р.). По-перше, Інтернет не був тоді ще поширеним інструментом, по-друге, ісламісти лише ставали сильніші. Початок конфлікту Аль-Каїди і талібів зі США започаткував другий етап. Третім етапом $є$ нинішня ситуація, яка змінилася в результаті виникнення Ісламської держави (ISIS). Доведено, що е-джихад - ие кониепиія, щуо прийнята й використовується в науиі протягом деякого часу. Мета статті - перевірити, чи відповідає діяльність Ісламської держави та Аль-Каїди в Інтернеті конщепиії джихаду. Завдяки иььому поняття джихаду прояснено та зіткнулося з обраними прикладами діяльності. Науковиі стверджують, щуо «Ісламська держава» й «Каїда» використовують нові технологї для широкого розуміння джихаду, уключаючи бойові діï (kital).

Ключові слова: Е-джихад, джихад, кіберджихад, ISIS, Аль-Каїда.

(C) Мазур П., Нетреба А., 2020 